\title{
Redescription of Proteocephalus bagri and P. rhamdiae (Cestoda: Proteocephalidae), parasites of Rhamdia quelen (Siluriformes: Pimelodidae) from South America, with comments on morphological variation
}

\author{
Alicia A. Gil de Pertierra \\ Departamento de Ciencias Biológicas, Lab. 52, Facultad de Ciencias Exactas y Naturales, Pab. II, Ciudad Universitaria, \\ Universidad de Buenos Aires, C1428EHA-Buenos Aires, Argentina
}

Key words: Proteocephalidae, Siluriformes, Proteocephalus bagri, Proteocephalus rhamdiae, morphological variation, multivariate analysis

\begin{abstract}
The pimelodid fish Rhamdia quelen (Quoy et Gaimard, 1824) in South America harbours two species of proteocephalid cestodes, Proteocephalus bagri Holcman-Spector et Mañé-Garzón, 1988 and P. rhamdiae Holcman-Spector et MañéGarzón, 1988. These species are redescribed based on a detailed morphological study, supported by multivariate analysis (principal component analysis). Features distinguishing these species are: (1) the shape of proglottides, (2) the mean number of testes, (3) the topography of vitelline follicles, (4) the thickness of internal longitudinal musculature, (5) the mean number of uterine branches, (6) the ratio of cirrus pouch length to proglottis width, (7) the shape of ovary in mature and gravid proglottides and (8) the genital pore position in mature proglottides. The specific status of $P$. bagri and $P$. rhamdiae is confirmed and neotypes of both species are designated.
\end{abstract}

During a parasitological survey of fishes from ChisChis and Chascomus lagoons, Buenos Aires Province, Argentina, specimens of Proteocephalus Weinland, 1858 were collected from the intestine of Rhamdia quelen (Quoy et Gaimard, 1824). Holcman-Spector and Mañé-Garzón (1988) described Proteocephalus bagri and $P$. rhamdiae in Rhamdia sapo Valenciennes, 1840 (=R. quelen sensu Silvergrip, 1996) from Uruguay; however, the material recently collected from the same host was difficult to identify as $P$. bagri and $P$. rhamdiae since the original descriptions of these species are incomplete and details on some morphological structures are confusing. Besides, there is high variability in the shape of proglottides, overlapping number of testis, low variability in the ratio of genital pore to the mature proglottis length, the ratio of the cirrus pouch length to the mature proglottis width, and the ratio of the width of mature ovary to the width of mature proglottis. Moreover, there is homogeneity in the width of scolices and presence of glandular cells, position of the vagina and position of the genitalia to the internal longitudinal musculature in cross sections of the proglottides.

Morphological and geographical intraspecific variability is well documented in species of the genus Proteocephalus parasitising Holarctic fishes (Hanzelová and Špakulová 1992, Scholz and Hanzelová 1994, Hanzelová et al. 1995a, b, 1999, Scholz et al. 1998).

Traditionally, species of Proteocephalus have been described on the basis of a set of morphometric characters and ratios, and more recently, multivariate techniques such as Principal Component Analysis (PCA) have been used to distinguish species in other groups of helminths (Bray and des Clers 1992, Höglund and Thulin 1992, Flores and Baccalá 1998, Jackson and Tinsley 1998, Tinsley and Jackson 1998, Cremonte et al. 2000).

The aim of the present work is to redescribe $P$. bagri and $P$. rhamdiae based on a detailed morphological study, supported by multivariate analysis.

\section{MATERIALS AND METHODS}

One hundred and twenty five Rhamdia quelen (Siluriformes: Pimelodidae) were examined for helminths. The fish were collected at Chis-Chis and Chascomus lagoons, Buenos Aires Province, Argentina, belonging to an extensive lagoon system of the Salado River basin. Sampling was carried out monthly from April 1985 to December 1986. Worms found in the intestine were isolated and placed in lukewarm water for relaxation, and then fixed in alcohol-formalin-acetic acid (AFA) or in $70 \%$ ethanol. Entire tapeworms were stained with Langeron's alcoholic chlorhydric carmine (Langeron 1949), differentiated in acid ethanol, dehydrated through a graded ethanol series, cleared in beechwood creosote and mounted in Canada balsam. Cross sections of the proglottides were stained following the same procedure. Voucher specimens have been deposited at the Colección Helmintológica del Museo Argentino de Ciencias Naturales "Bernardino Rivadavia", Buenos Aires, Argentina (MACN) and at the Institute of Parasitology, Academy of Sciences of the Czech Republic, České Budějovice, Czech Republic (IPASCR). Additional specimens of $P$. bagri and $P$. rhamdiae deposited at the 
Natural History Museum, Geneva, Switzerland (MHNG) and paratypes of Proteocephalus brooksi García-Prieto, Rodríguez et Pérez-Ponce de León, 1996 from Rhamdia guatemalensis Günther, 1864 deposited at the Colección Nacional de Helmintos (CNHE) del Instituto de Biología, Universidad Nacional Autónoma de México, México (Nos. 2726 and 2727) were also studied.

Type specimens of $P$. rhamdiae and $P$. bagri, originally deposited at the Colección Helmintológica, Laboratorio de Zoología de Invertebrados, Facultad de Humanidades y Ciencias, Uruguay (FHCU) (P. rhamdiae holotype No. CPU 0522 and paratypes Nos. CPU 0523-0528, P. bagri holotype No. CPU 0515 and paratypes Nos. CPU 0516-0521) have been lost (personal communication of R. Ponce de León, curator of that helminthological collection). Fortunately, HolcmanSpector and Mañé-Garzón also deposited additional spirit preserved specimens of both species (BP/9001). This material was available to the author in order to prepare cross sections and new whole mounts following the procedure described above; afterwards, these specimens were deposited at FHCU.

All measurements are given in micrometres, unless otherwise stated, as the range followed by the mean, standard deviation and the number of measurements $(n)$ in parentheses. The following abbreviations are used throughout the text: AM $=$ Argentinean material, $\mathrm{PM}=$ Paraguayan material, $\mathrm{UM}=$ Uruguayan material, $\mathrm{OD}=$ original description, $\mathrm{PCA}=$ principal component analysis, and $\mathrm{PC}=$ principal component Illustrations were made with the aid of a camera lucida on a Zeiss Axioscope microscope.

\section{Morphological study and Principal Component Analysis}

The variables and ratios used in the morphological study were chosen on the basis of their diagnostic value as currently used by specialists for the diagnosis of proteocephalideans (de Chambrier and Vaucher 1999). They can be accurately measured and they are usually not influenced by contraction of the strobila unless extreme. Only complete specimens possessing mature and at least first gravid proglottides were considered in the analysis. Measurements of genital organs from mature and gravid proglottides were considered separately, and sets of measurements from 3-6 proglottides per strobila were taken for each variable representing an individual worm. The number of testes was determined in mature proglottides, since these degenerate as the proglottis becomes gravid. Only cestodes with a complete data-set were included in the analysis. Measurements of eggs, ovarian isthmus width and diameter of vaginal sphincter were not included in the analysis, due to difficulties in obtaining complete data-sets of these structures. A PCA was carried out to determine the multivariate relation between 27 variables and 4 ratios measured in 42 specimens ( 17 from Argentina, 18 from Uruguay and 7 from Brazil) to assess the correct taxonomical status of $P$. rhamdiae and $P$. bagri. Additional worms of AM and UM (30 specimens of P. bagri and 40 specimens of $P$. rhamdiae) were also studied. The following metrical variables and ratios were included in the analysis: (1) total length, (2) number of proglottides, (3) proliferation zone length (unsegmented region between the posterior end of suckers and the first distinct proglottis of the strobila), (4) proliferation zone width, (5) scolex maximum width, (6) sucker length, (7) sucker width, (8) immature proglottis length, (9) immature proglottis width, (10) mature proglottis length, (11) mature proglottis width, (12) ovary width in mature proglottis, (13) cirrus pouch length in mature proglottis, (14) cirrus pouch width in mature proglottis, (15) genital pore position in mature proglottis, (16) ratio of genital pore position to mature proglottis length (percentage from anterior margin of proglottis), (17) ratio of cirrus pouch length to mature proglottis width, (18) gravid proglottis length, (19) gravid proglottis width, (20) ovary width in gravid proglottis, (21) uterus width, (22) ratio of gravid proglottis width to uterus width, (23) cirrus pouch length in gravid proglottis, (24) cirrus pouch width in gravid proglottis, (25) genital pore position in gravid proglottis, (26) ratio of genital pore position to gravid proglottis length (percentage from anterior margin of proglottis), (27) total number of testes (in mature proglottis), (28) diameter of testis (in mature proglottis), (29) ovary length in mature proglottis, (30) ovary length in gravid proglottis, and (31) number of uterine branches.

The data matrix for the PCA was processed with the NTSYS-pc Numerical Taxonomy and Multivariate Analysis System, version 1.70 (1992)

\section{RESULTS}

Proteocephalus bagri Holcman-Spector et MañéGarzón, 1988

Figs. 1-8

Description (based on 30 specimens and measurements of 16 specimens): Proteocephalidae, Proteocephalinae. Testes, ovary and uterus medullary; vitelline follicles mostly medullary, partly paramuscular. Medium size worms $(45-160 \mathrm{~mm})$, flattened dorsoventrally. Strobila acraspedote, bearing 66-202 (117 \pm $44, \mathrm{n}=16)$ proglottides. About 90 immature proglottides, 12-30 mature proglottides, and 20 gravid proglottides.

Scolex slightly wider than proliferation zone, with elongated bottle-shaped glandular cells, with granular inclusions in apical region (Fig. 1) and external margin of suckers (Fig. 2); scolex 230-410 (340 $\pm 53, \mathrm{n}=16)$ wide, in some specimens inconspicuous microtriches were observed. Suckers uniloculate, strongly muscular, 120-230 (188 $\pm 35, \mathrm{n}=23)$ long, 80-200 $(140 \pm 34)$ wide. Proliferation zone, $4-25 \mathrm{~mm}(13 \pm 6, \mathrm{n}=16)$ long, 200-400 (294 \pm 62$)$ wide, with elongated granular gland cells.

Immature proglottides quadrangular or longer than wide, $270-1230(680 \pm 228, \mathrm{n}=64)$ long, 480-950 (685 \pm 122 ) wide; mature proglottides longer than wide (Fig. 3), 690-2710 (1375 $\pm 490, \mathrm{n}=69)$ long, 490-1410 (880 \pm 191 ) wide; gravid proglottides much longer than wide (Fig. 4), 850-3250 (1815 $\pm 720, \mathrm{n}=37$ ) long, 690-1430 $(1015 \pm 204)$ wide. Last proglottis $1490-3400$ long, 690920 wide.

Osmoregulatory canals between testes and vitelline follicles, dorsal canal 5-10 in diameter, ventral canal 1025 in diameter. Internal longitudinal musculature well developed, forming thin fibre bundles (Figs. 6, 7). 

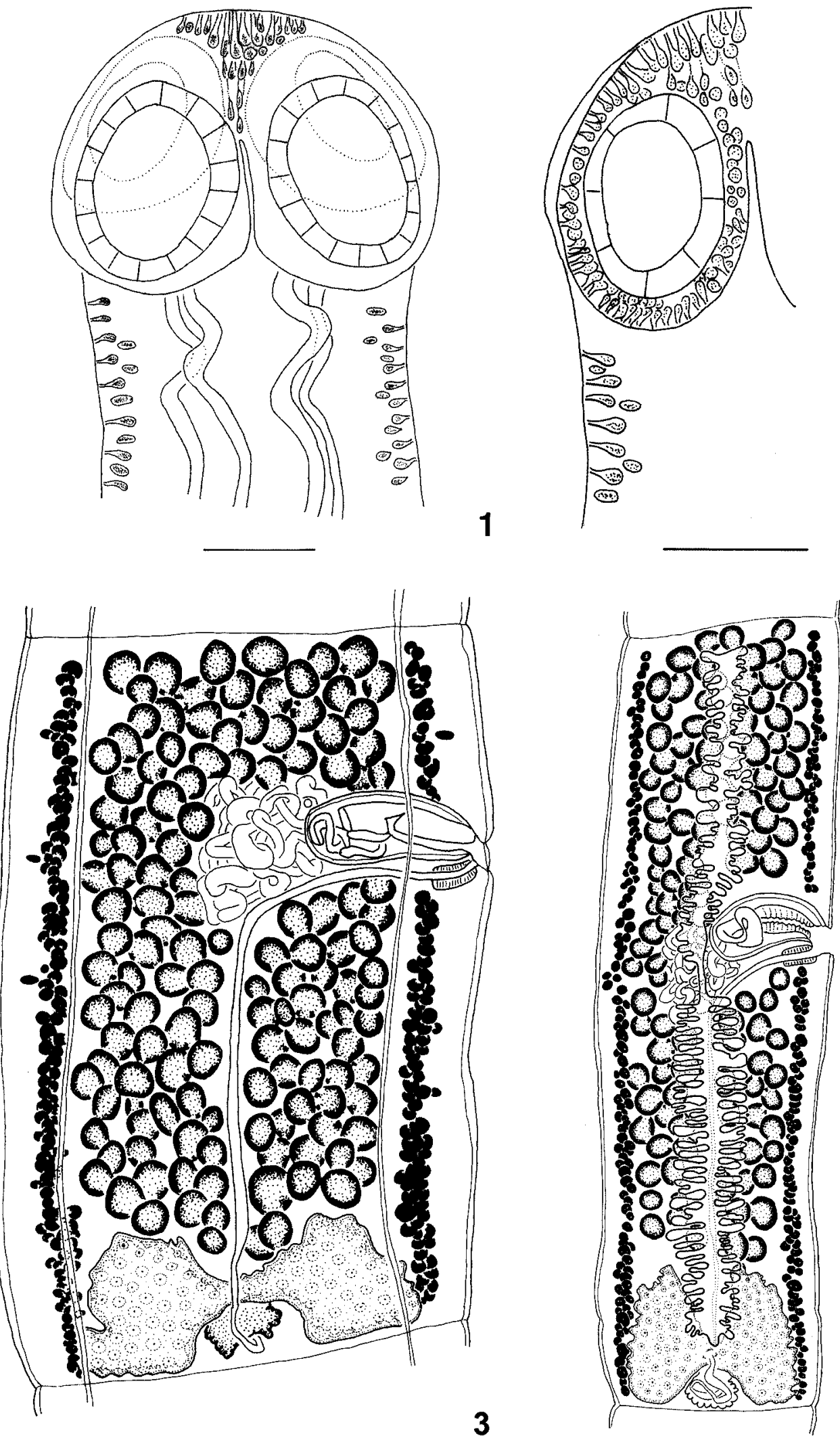

Figs. 1-4. Proteocephalus bagri Holcman-Spector et Mañé-Garzón, 1988. Fig. 1. Scolex, detail of gland cells in the apex and proliferation zone. Fig. 2. Scolex, detail of gland cells in external margin of suckers. Fig. 3. Mature proglottis, dorsal view. Fig. 4. Gravid proglottis, ventral view. Scale bars: Figs. 1, $2=100 \mu \mathrm{m}$; Figs. $3,4=500 \mu \mathrm{m}$. 


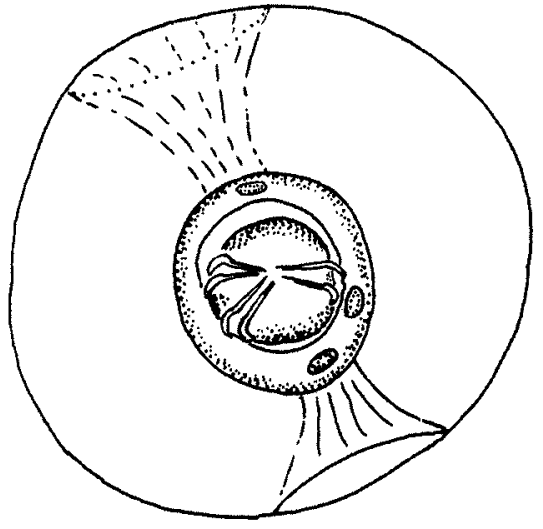

5

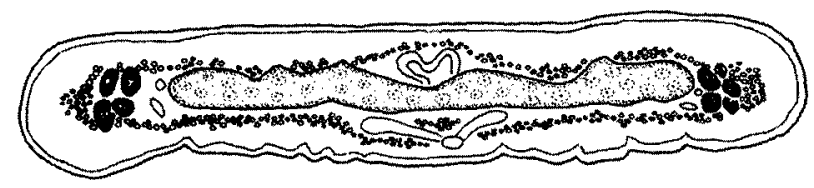

6

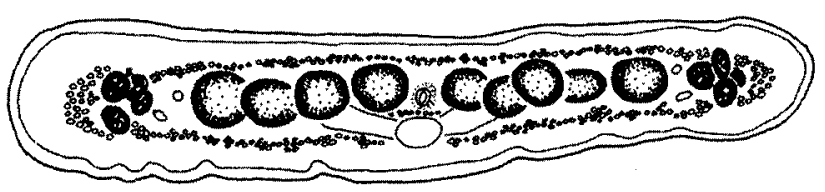

Figs. 5-7. Proteocephalus bagri Holcman-Spector et Mañé-Garzón, 1988. Fig. 5. Egg drawn in distilled water after fixation. Fig. 6. Cross section of mature proglottis at ovary level. Fig. 7. Cross section of proglottis at testicular and uterus level. Scale bars: Fig. $5=50 \mu \mathrm{m}$; Figs. $6,7=500 \mu \mathrm{m}$.

Testes medullary, 79-198 $(119 \pm 23, \mathrm{n}=54)$ in mature proglottides, spherical, 30-125 $(72 \pm 19, \mathrm{n}=61)$ in diameter, in one layer (Fig. 7), occasionally a low number of testes lying in second layer, in one field, only interrupted by cirrus pouch, vas deferens and vaginal canal all along proglottis and usually not surpassing osmoregulatory canals (Fig. 3). Cirrus pouch pyriform to globular, with thick muscular wall, 210-540 (385 \pm $152, \mathrm{n}=69)$ long, 100-280 (185 \pm 38$)$ wide, occupying $31-57 \%(44 \pm 6, n=69)$ of proglottis width in mature proglottides. Genital pores irregularly alternating, 15$45 \%(33 \pm 6, \mathrm{n}=69)$ from anterior margin of proglottis. Vas deferens bulky and strongly coiled, 40-60 in diameter, usually surpassing body midline in mature proglottides (Fig. 3).

Vagina thick-walled, always posterior to cirrus pouch, 40-60 in diameter; muscular sphincter present. Ovary medullary with slight dorsal outgrowth reaching cortex, bilobed in immature and mature proglottides in cross sections (Fig. 6), 80-520 (260 $\pm 105, \mathrm{n}=69)$ long, $270-1030$ (605 \pm 152$)$ wide, occupying 50-76\% (68 \pm 8 , $\mathrm{n}=69$ ) of proglottis width; in gravid proglottides lobes anteriorly expanded (Figs. 4, 8e, f), 115-650 (610 \pm 151 , $\mathrm{n}=38)$ long, 500-1100 (710 \pm 126$)$ wide; ovarian isthmus 75-140 $(90 \pm 24, \mathrm{n}=7)$ wide. Vitelline follicles medullary, in two lateral bands, some follicles slightly paramuscular through dorsal and ventral cortex (Figs. 6, 7), concentrated in mid-lateral region of proglottis; interrupted by vagina and cirrus pouch, reaching 95$97 \%$ of total proglottis length.

Uterine primordium originated as a cortical cylindrical mass of chromophil cells in immature proglottides. Uterine branches developed in medulla (Fig. 7), slightly ventrally overlapping ovary in gravid proglottides (Fig. 4). Medullary uterine branches occupying 16-57\% (32 \pm $10, \mathrm{n}=37$ ) of gravid proglottis width, with a total of 48 -
$108(79 \pm 22, n=26)$ lateral branches. Eggs released through a ventral longitudinal slit. Eggs with thin external shell, 71-74 in diameter; thick hyaline outer envelope; embryophore bilayered, 29-33; oncosphere 20-24 in diameter; hooks 6-8 long (Fig. 5).

$\mathrm{H}$ o $\mathrm{s}$ t : Rhamdia quelen (Quoy et Gaimard, 1824) (Siluriformes: Pimelodidae).

Localities and material studied: Chis-Chis and Chascomus lagoons (10.4.1985 to 18.12.1986), Ciudad de Chascomus, Provincia de Buenos Aires, Argentina $\left(35^{\circ} 34^{\prime} \mathrm{S}\right.$; $\left.58^{\circ} 01^{\prime} \mathrm{W}\right), 5$ specimens deposited at MACN, Nos. 399/1-5, and 2 specimens deposited at IPASCR, No. C-342. El Sauce and El Diario lagoons (18.10.1983), Department of Maldonado, Uruguay ( $34^{\circ} 54^{\prime} \mathrm{S}$; $\left.54^{\circ} 57^{\prime} \mathrm{W}\right), 8$ specimens deposited at FHCU, neotype No. AP/11485 and 7 vouchers Nos. AP/11486-11492, and Dos Patos lagoon, Porto Alegre, Brazil $\left(30^{\circ} 02^{\prime} \mathrm{S}\right.$; $\left.51^{\circ} 12^{\prime} \mathrm{W}\right), 3$ specimens deposited at MHNG INVE 27687-27689. Additional specimens of AM and UM were examined for redescription.

Site of infection: Middle intestine.

Remarks: Since Rhamdia spp. are distributed in the Neotropical region, a comparison of $P$. bagri with related species was made considering those species occurring in Rhamdia spp. and other freshwater fishes of South America.

Out of 21 species of Proteocephalus parasitising freshwater fishes described from South America, 14 share with $P$. bagri the absence of apical organ. Among these, P. hemioliopteri (Rego, 1984); P. hobergi de Chambrier et Vaucher, 1999; P. jandia Woodland, 1934 (from Rhamdia sp.); P. macrophallus (Diesing, 1850); P. microscopicus (Woodland, 1935); P. piramutab (Woodland, 1933); P. pimelodi (Gil de Pertierra, 1995); P. platystomi Lynsdale, 1959; P. serrasalmus Rego et Pavanelli, 1990; and P. vladimirae de Chambrier et 

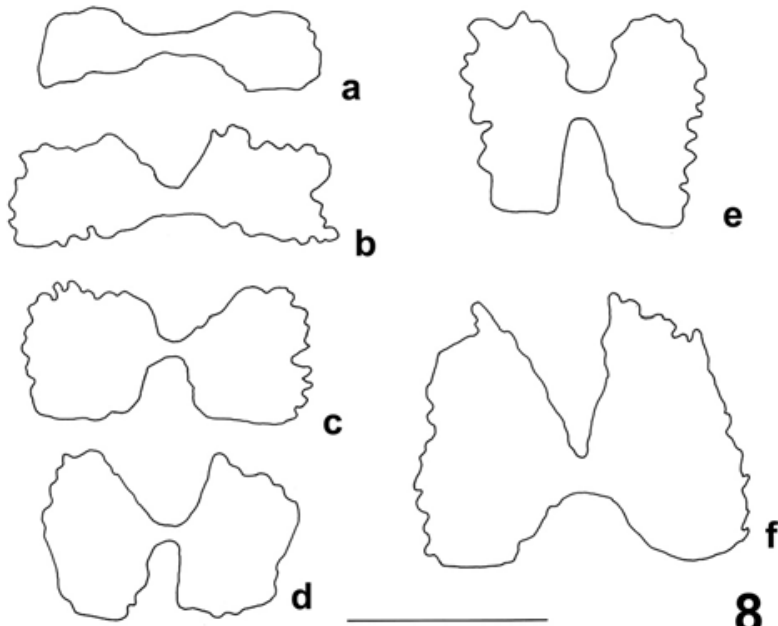

8

Fig. 8. Proteocephalus bagri Holcman-Spector et MañéGarzón, 1988. Development of ovary in immature to gravid proglottides: a - ovary in immature proglottis, b-d - ovaries in mature proglottides, $\mathbf{e}, \mathbf{f}$ - ovaries in gravid proglottides. Scale bar $=500 \mu \mathrm{m}$

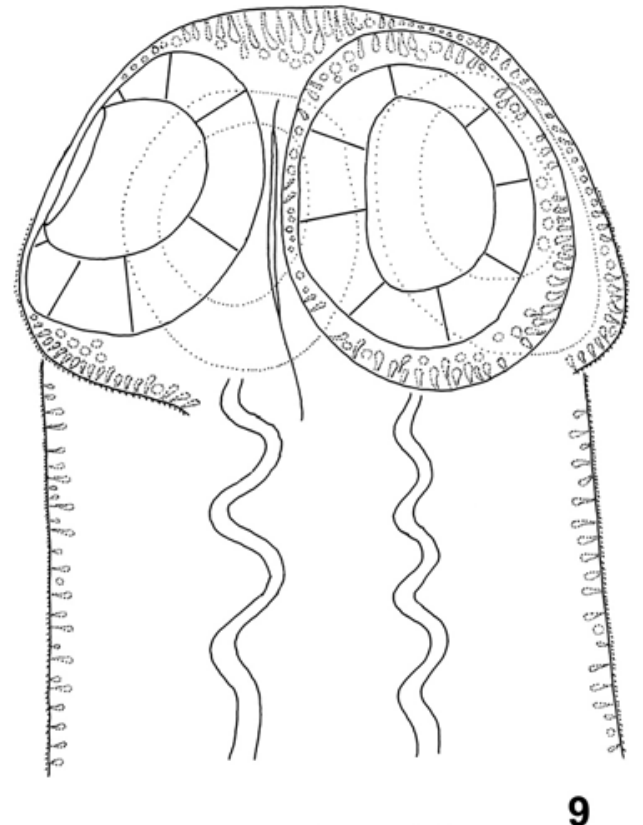

Fig. 9. Proteocephalus rhamdiae Holcman-Spector et MañéGarzón, 1988. Scolex, gland cells in the apex, external margin of suckers and proliferation zone. Scale bar $=100 \mu \mathrm{m}$.

Vaucher, 1999 have a lower number of testes $(38-<$ 100) than P. bagri (79-198). In addition to the low number of testes, $P$. jandia has a vagina anterior to the cirrus pouch. Data on the number of testes are lacking for P. kuyukuyu Woodland, 1935; however, this species was considered a species inquirenda by Rego et al. (1999). P. brooksi García-Prieto et al., 1996 (from $R$. guatemalensis), $P$. pilarensis de Chambrier et Vaucher, 1999 and $P$. renaudi de Chambrier et Vaucher, 1994 are distinguished by having the vagina anterior or posterior to the cirrus pouch vs. vagina always posterior in $P$. bagri. In cross sections of the paratypes of $P$. brooksi the vitelline follicles were mostly in the cortex. In view of the medullary position of the ovary, testes and uterus and the cortical position of vitelline follicles, P. brooksi should probably be transferred to the genus Nomimoscolex, subfamily Zygobothriinae.

The differences between our specimens and the OD by Holcman-Spector and Mañé-Garzón (1988) were: scolex width, 230-410 (OD = 124-149), all the specimens deposited in Uruguay (BP/9001) have larger scolices; presence of unicellular glands at the apex, external margin of suckers and in the proliferation zone (not mentioned in the OD); ovary medullary with slight dorsal outgrowth reaching the cortex in cross sections (not mentioned in the OD); vitelline follicles medullary and paramuscular to the dorsal and ventral cortex in cross sections (no figures of cross sections in the OD); vitelline follicles interrupted by the vagina and cirrus pouch (only figured in Plate $1 \mathrm{c}$, $\mathrm{f}$ of the $\mathrm{OD}$ ), vitelline follicles reaching $95-97 \%$ of total proglottis length (OD $=$ only mentioned to be extended along the whole length of the proglottis, figured in Plate $1 \mathrm{c}$, $\mathrm{f}$ as slightly surpassing the ovary); vagina always posterior (OD = anterior or posterior); absence of genital atrium $(\mathrm{OD}=$ presence of genital atrium in the text and not shown in Plate 1c, f); testes 79-198 (OD = 71-89); total number of uterine branches 48-108 $(\mathrm{OD}=68-96)$.

Proteocephalus rhamdiae Holcman-Spector et Mañé-Garzón, 1988

Figs. 9-17

Description (based on 40 specimens and measurements of 26 specimens): Proteocephalidae, Proteocephalinae. Testes, ovary and uterus medullary; vitelline follicles medullary, partly paramuscular. Worms of medium size, 50-200 mm long, flattened dorsoventrally. Strobila acraspedote, bearing 62-290 $(145 \pm 52, \mathrm{n}=26)$ proglottides. About 70 immature proglottides, 20-40 mature proglottides, and 100 gravid proglottides.

Scolex usually wider than proliferation zone, with elongated bottle-shaped glandular cells, with granular inclusions in apex and external margin of suckers; scolex width 250-520 $(370 \pm 69, \mathrm{n}=24)$. Suckers uniloculate, strongly muscular, 130-290 $(200 \pm 39, \mathrm{n}=$ 30) long, 90-230 (160 \pm 33$)$ wide. Proliferation zone 3$35 \mathrm{~mm}(10 \pm 6, \mathrm{n}=26)$ long, 180-600 (385 \pm 110$)$ wide. Microtriches on internal surface of suckers, around them and in first portion of proliferation zone (Fig. 9).

Immature proglottides wider than long, 200-960 (515 $\pm 178 ; \mathrm{n}=92)$ long, $640-1800(995 \pm 202)$ wide; mature proglottides wider than long or quadrangular (Fig. 10), 


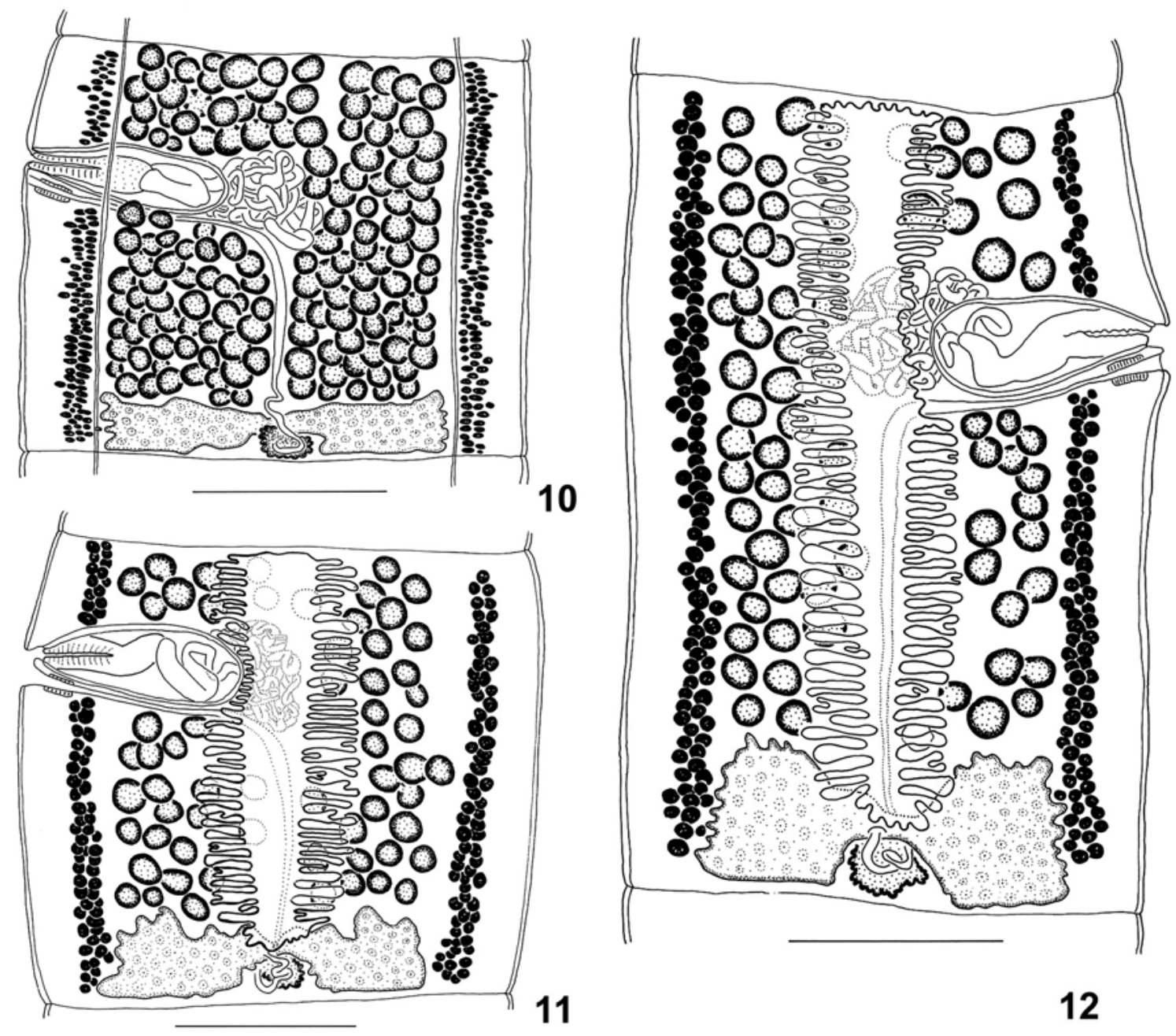

Figs. 10-12. Proteocephalus rhamdiae Holcman-Spector et Mañé-Garzón, 1988. Fig. 10. Mature proglottis, dorsal view. Figs. 11, 12. Gravid proglottides, ventral view, note two different morphotypes. Scale bars: Figs. 10-12 = 500 $\mu \mathrm{m}$.

400-1350 (895 $\pm 220, \mathrm{n}=106)$ long, 950-1950 (1340 \pm 194) wide; gravid proglottides wider than long, quadrangular (Fig. 11) or longer than wide (Fig. 12), 750$3260(1450 \pm 420, \mathrm{n}=120)$ long, 1020-2100 (1440 \pm 220 ) wide. Last proglottis 3200-3700 long, 1010-1200 wide.

Osmoregulatory canals between testes and vitelline follicles, ventral canal 20-35 in diameter, dorsal canal $10-15$ in diameter. Internal longitudinal musculature strongly developed (Figs. 13-15), forming packs of thick bundles, 40-60 in diameter.

Testes medullary, 91-239 $(150 \pm 24, \mathrm{n}=86)$ in mature proglottides; slightly oval to spherical, 50-100 $(74 \pm 20, \mathrm{n}=87)$ long, 50-75 $(62 \pm 7, \mathrm{n}=20)$; one layer in cross sections (Figs. 14, 15), in a single field, interrupted by cirrus pouch, vas deferens and vaginal canal, usually not surpassing osmoregulatory canals. Cirrus pouch pyriform, thick-walled, 310-640 (455 \pm $74, \mathrm{n}=106)$ long, 80-250 (180 \pm 33$)$ wide, occupying
$20-45 \%(34 \pm 5, \mathrm{n}=106)$ of proglottis width in mature proglottides. Genital pores irregularly alternating, 21$69 \%(38 \pm 7, \mathrm{n}=106)$ from anterior margin of proglottis. Vas deferens bulky and strongly coiled, 3040 in diameter, reaching body midline in mature proglottides.

Vagina thick-walled, always posterior to cirrus pouch, 40-70 in diameter, with inconspicuous muscular sphincter; sometimes 2-3 testes overlapping vagina at cirrus pouch level. Ovary medullary, with slight dorsal outgrowth reaching cortex (Fig. 15), ovarian lobes flattened to bilobed in immature to mature proglottides (Fig. 17a-c), and bilobed in cross sections, 90-320 (165 $\pm 45, \mathrm{n}=106)$ long, 680-1460 (930 \pm 154) wide, occupying $56-77 \%(69 \pm 4, \mathrm{n}=106)$ of proglottis width; ovarian lobes expand anteriorly in gravid proglottides (Fig. 17d, e), 150-450 (275 $\pm 72, \mathrm{n}=119)$ long, 620$1450(975 \pm 170)$ wide; ovarian isthmus 50-110 (75 \pm $16, \mathrm{n}=24)$ wide. Vitelline follicles medullary, arranged 


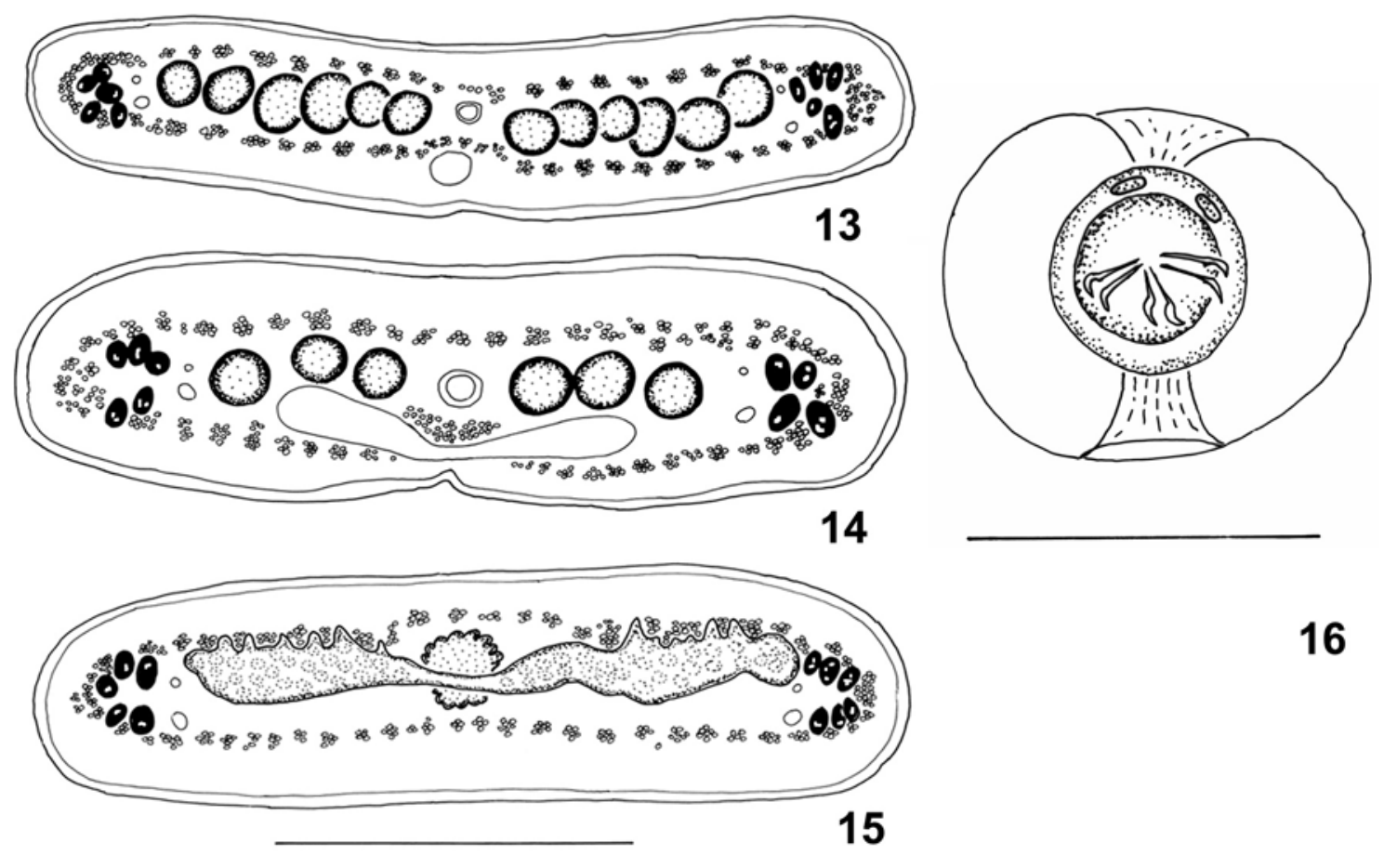

Figs. 13-16. Proteocephalus rhamdiae Holcman-Spector et Mañé-Garzón, 1988. Figs. 13-15. Cross sections of proglottides at level of testes, uterus and ovary, respectively. Fig. 16. Egg drawn in distilled water after fixation. Scale bars: Figs. 13-15=500 $\mu \mathrm{m}$; Fig. $16=50 \mu \mathrm{m}$.

in two lateral bands, some follicles paramuscular through dorsal and ventral cortex (Figs. 13-15), scarcely concentrated in mid-lateral region of proglottis; interrupted by vagina and cirrus pouch, reaching 96$98 \%$ of total proglottis length, with slight tendency to posterior concentration of follicles (Fig. 10).

Uterine primordium originating as cortical cylindrical mass of chromophil cells in immature proglottides (Fig. 13). Uterine branches developed in medulla (Fig. 15), slightly overlapping ovary ventrally in gravid proglottides. Medullary uterine branches occupying 14-61\% $(31 \pm 9, \mathrm{n}=119)$ of gravid proglottis width, 40-100 (55 $\pm 12, \mathrm{n}=85$ ) lateral branches per side. Eggs released through a ventral longitudinal slit. Eggs with thin external shell, 50-60 in diameter; thick hyaline outer envelope; embryophore bilayered, 27-32; oncosphere 20-22 in diameter; hooks 6-8 long (Fig. 16).

$\mathrm{H}$ o $\mathrm{s}$ t : Rhamdia quelen (Quoy et Gaimard, 1824) (Siluriformes: Pimelodidae).

Localities and material studied: Chis-Chis and Chascomus lagoons (10.4.1985 to 18.12.1986), Ciudad de Chascomus, Provincia de Buenos Aires, Argentina ( $\left.35^{\circ} 34^{\prime} \mathrm{S} ; 58^{\circ} 01^{\prime} \mathrm{W}\right), 12$ specimens deposited at MACN, Nos. 400/1-12, and 2 specimens deposited at IPASCR, No. C-343. El Sauce and El Diario lagoons (18.10.1983),

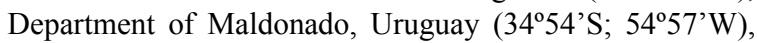
10 specimens deposited at FHCU, neotype No. 11493 and 9 vouchers Nos. AP/11494-11502, and Dos Patos lagoon
(25.7.1997), Porto Alegre, Brazil ( $\left.30^{\circ} 02^{\prime} \mathrm{S} ; 51^{\circ} 12^{\prime} \mathrm{W}\right), 4$ specimens deposited at MHNG, INVE 27685-27686 and MACN No. 401/1-2. Guayra Department, Yhaca-mi

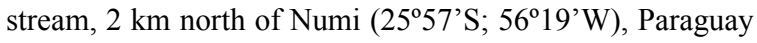
(26.3.1985), INVE 23357; Caaguazú Department, Güyraugua, $3 \mathrm{~km}$ east Ltr. Juna M. Frutos, Paraguay (13.04.1985), INVE 22358; Concepción Department, Estancia Santa Sofía $\left(24^{\circ} 39^{\prime} \mathrm{S}\right.$; 57 $\left.57^{\circ} \mathrm{9} \mathrm{W}\right)$, Paraguay (29.10.1987), INVE 23359; San Pedro Department, Tapiracuayi stream, $8 \mathrm{~km}$ north-west of San Estanislao (24³9'S; 56²6'W), Paraguay (25.10.1989), INVE 23712; Neembucu Department, $18 \mathrm{~km}$ east of San Lorenzo Neembucu, lagoons of Río Paraná (26 $47^{\prime} S$; 57 $47^{\circ} \mathrm{W}$ ), Paraguay (16.10.1989), INVE 22360, 5 specimens, deposited at MHNG. Additional specimens of AM and UM were examined for redescription.

Site of infection: Middle intestine.

Remarks: Proteocephalus rhamdiae and P. bagri agree in the following characters: scolex width 250-520 (370) vs. 230-410 (340); sucker length 130-290 (200) vs. 120-230 (188); posterior vagina; number of testes highly variable 91-239 (150) vs. 79-198 (119); slight dorsal outgrowths of ovary in cross sections, reaching cortex and expanding anteriorly in gravid proglottides in both species, with negligible variability in ovary width to proglottis width, 56-77 (69)\% vs. 50-76 (68)\%; vitelline follicles paramuscular through dorsal and ventral cortex; uterine primordium cortical; uterine 


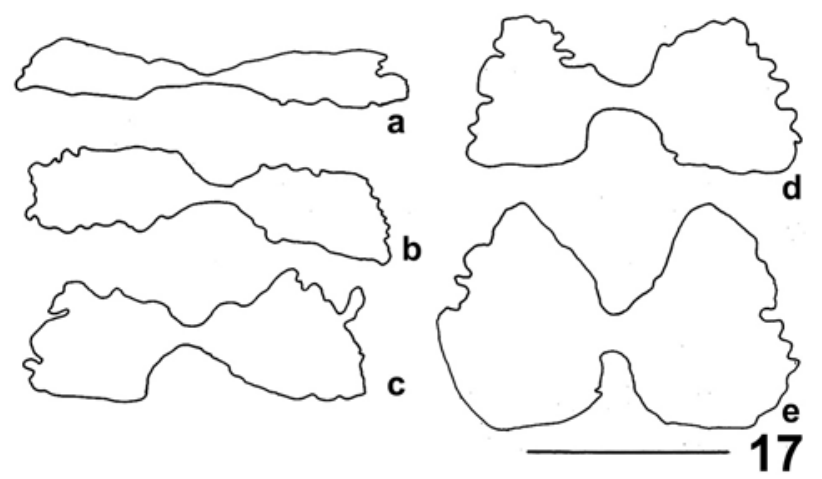

Fig. 17. Proteocephalus rhamdiae Holcman-Spector et Mañé-Garzón, 1988. Development of ovary in immature to gravid proglottides: a - ovary in immature proglottis, b, c - ovaries in mature proglottides, d, e - ovaries in gravid proglottides. Scale bar $=500 \mu \mathrm{m}$.
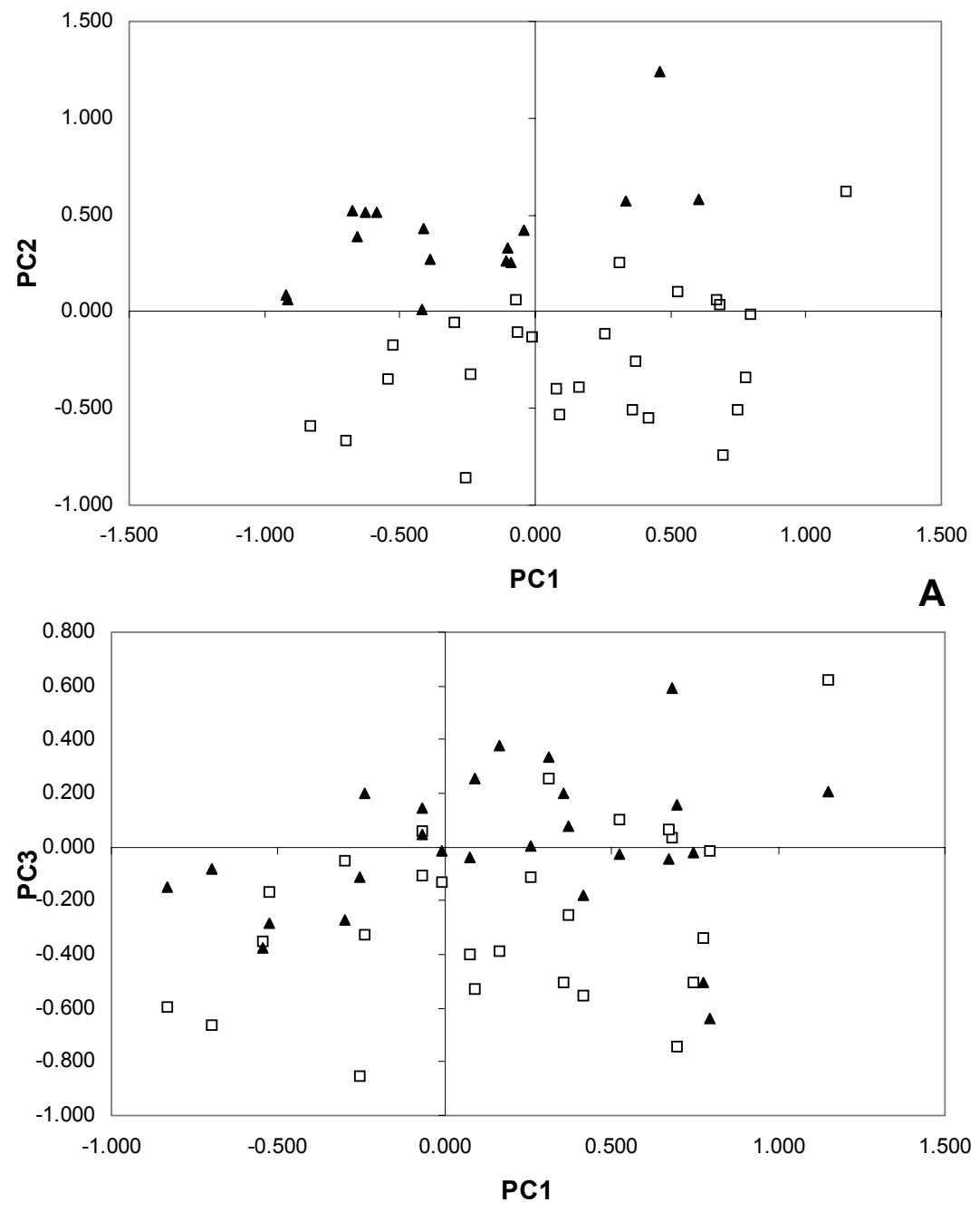

B

Fig. 18. Plot of individual component scores from a PCA of 42 specimens of Proteocephalus spp. complex. A - PC1 vs. PC2; B - PC1 vs. PC3. Key: black triangle, $P$. bagri $(\mathrm{n}=16)$; empty square, $P$. rhamdiae $(\mathrm{n}=26)$. branches occupying $14-61 \%$ (31) vs. $16-57 \%$ (32) of proglottis width. Differentiation of these species is further complicated by the high variability observed in the shape of proglottides of $P$. rhamdiae. About $20 \%$ of specimens have quadrangular mature proglottides and gravid proglottides longer than wide; in this case the ovary expands anteriorly as in $P$. bagri.

Proteocephalus rhamdiae can be distinguished from $P$. bagri by the smaller ratio of cirrus pouch to proglottis width, 20-45 (34)\% vs. 31$54(44) \%$, differing in the position of the genital pore, $21-69(38) \%$ vs. 15 $45(33) \%$, probably due to variation in proglottis shape. The tendency to posterior concentration of vitelline follicles observed in $P$. rhamdiae does not occur in P. bagri. The number of uterine branches is smaller in $P$. rhamdiae 40-100 (55) than in $P$. bagri 48-108 (79). The internal longitudinal musculature is strongly developed and forms packs of thick bundles in $P$. rhamdiae, whereas it is less developed in P. bagri. Eggs have the typical shape found in most proteocephalideans, and there are small differences in size of oncosphere (20-22 vs. $20-24)$ and embryophore (27-32 vs. 29-33) of $P$. rhamdiae and $P$. bagri, but they differ more in the size of the shell (50-60 vs. 71-74).

Proteocephalus rhamdiae was originally described by HolcmanSpector and Mañé-Garzón (1988) from $R$. quelen from Uruguay, and later was reported by de Chambrier and Vaucher (1999) from $R$. quelen from Paraguay. The latter material was not included in this study due to the small number of specimens, some being immature and contracted; these specimens share the arrangement in cross sections of ovary, vitelline follicles and uterus with AM and UM. De Chambrier and Vaucher (1999) mentioned 107-140 testes, but 154 and 161 testes were counted in this study in the same material. The diameter of scolices in PM is smaller than AM and UM, but this could be due to contraction and immature state. 
Gil de Pertierra: Redescription of Proteocephalus bagri and P. rhamdiae

Table 1. Correlation matrix of Proteocephalus spp. complex (high negative and high positive coefficients in bold).

\begin{tabular}{|c|c|c|c|c|c|c|c|c|c|c|c|c|c|c|c|c|c|c|c|c|c|c|c|c|c|c|c|c|c|c|c|}
\hline & 1 & 2 & 3 & 4 & 5 & 6 & 7 & 8 & 9 & 10 & 11 & 12 & 13 & 14 & 15 & 16 & 17 & 18 & 19 & 20 & 21 & 22 & 23 & 24 & 25 & 26 & 27 & 28 & 29 & 30 & 31 \\
\hline 1 & 1.00 & & & & & & & & & & & & & & & & & & & & & & & & & & & & & & \\
\hline 2 & 0.61 & 1.00 & & & & & & & & & & & & & & & & & & & & & & & & & & & & & \\
\hline 3 & -0.18 & -0.50 & 1.00 & & & & & & & & & & & & & & & & & & & & & & & & & & & & \\
\hline 4 & -0.13 & -0.22 & 0.05 & 1.00 & & & & & & & & & & & & & & & & & & & & & & & & & & & \\
\hline 5 & -0.21 & -0.48 & 0.47 & 0.68 & 1.00 & & & & & & & & & & & & & & & & & & & & & & & & & & \\
\hline 6 & -0.10 & -0.45 & 0.60 & 0.46 & 0.80 & 1.00 & & & & & & & & & & & & & & & & & & & & & & & & & \\
\hline 7 & -0.12 & -0.41 & 0.44 & 0.46 & $\mathbf{0 . 7 7}$ & 0.78 & 1.00 & & & & & & & & & & & & & & & & & & & & & & & & \\
\hline 8 & 0.05 & -0.39 & 0.32 & -0.01 & 0.22 & 0.34 & 0.27 & 1.00 & & & & & & & & & & & & & & & & & & & & & & & \\
\hline 9 & 0.15 & 0.10 & -0.34 & 0.29 & 0.01 & -0.11 & 0.05 & -0.37 & 1.00 & & & & & & & & & & & & & & & & & & & & & & \\
\hline 10 & 0.23 & -0.27 & 0.14 & 0.03 & 0.07 & 0.23 & 0.09 & 0.79 & -0.34 & 1.00 & & & & & & & & & & & & & & & & & & & & & \\
\hline 11 & 0.30 & 0.23 & -0.31 & 0.48 & 0.19 & 0.02 & 0.22 & -0.25 & 0.74 & -0.29 & 1.00 & & & & & & & & & & & & & & & & & & & & \\
\hline 12 & 0.31 & 0.21 & -0.30 & 0.49 & 0.21 & 0.02 & 0.23 & -0.23 & 0.71 & -0.27 & 0.99 & 1.00 & & & & & & & & & & & & & & & & & & & \\
\hline 13 & 0.10 & -0.15 & 0.06 & 0.50 & 0.48 & 0.28 & 0.31 & 0.32 & 0.41 & 0.25 & 0.60 & 0.61 & 1.00 & & & & & & & & & & & & & & & & & & \\
\hline 14 & 0.03 & -0.45 & 0.42 & 0.20 & 0.40 & 0.46 & 0.34 & 0.45 & -0.02 & 0.53 & 0.13 & 0.16 & 0.53 & 1.00 & & & & & & & & & & & & & & & & & \\
\hline 15 & 0.23 & -0.31 & 0.20 & -0.03 & 0.08 & 0.28 & 0.07 & 0.78 & -0.30 & 0.96 & -0.28 & -0.27 & 0.24 & 0.58 & 1.00 & & & & & & & & & & & & & & & & \\
\hline 16 & -0.21 & -0.07 & 0.06 & -0.50 & -0.32 & -0.14 & -0.36 & -0.02 & -0.23 & 0.09 & -0.57 & -0.55 & -0.46 & -0.19 & 0.16 & 1.00 & & & & & & & & & & & & & & & \\
\hline 17 & -0.34 & -0.47 & 0.47 & -0.23 & 0.10 & 0.21 & -0.03 & 0.60 & -0.61 & 0.61 & -0.73 & -0.71 & 0.05 & 0.34 & 0.60 & 0.38 & 1.00 & & & & & & & & & & & & & & \\
\hline 18 & 0.40 & 0.12 & -0.19 & -0.11 & -0.18 & -0.27 & -0.31 & 0.32 & -0.24 & 0.67 & -0.23 & -0.21 & -0.05 & 0.20 & 0.72 & 0.35 & 0.29 & 1.00 & & & & & & & & & & & & & \\
\hline 19 & 0.14 & 0.19 & -0.24 & 0.37 & 0.09 & -0.08 & 0.14 & -0.25 & 0.67 & -0.38 & 0.92 & 0.90 & 0.51 & -0.09 & -0.44 & -0.49 & -0.61 & -0.34 & 1.00 & & & & & & & & & & & & \\
\hline 20 & 0.15 & 0.23 & -0.29 & 0.29 & 0.03 & -0.17 & 0.08 & -0.22 & 0.61 & -0.35 & 0.89 & 0.88 & 0.47 & -0.10 & -0.40 & -0.45 & -0.59 & -0.28 & 0.97 & 1.00 & & & & & & & & & & & \\
\hline 21 & 0.41 & 0.43 & -0.40 & 0.17 & -0.26 & -0.32 & -0.16 & -0.33 & 0.63 & -0.30 & 0.65 & 0.62 & 0.23 & -0.26 & -0.32 & -0.28 & -0.56 & -0.07 & 0.72 & 0.69 & 1.00 & & & & & & & & & & \\
\hline 22 & 0.48 & 0.46 & -0.38 & -0.13 & -0.45 & -0.33 & -0.40 & -0.25 & 0.21 & -0.07 & 0.01 & -0.02 & -0.23 & -0.33 & -0.03 & 0.09 & -0.25 & 0.36 & 0.02 & 0.01 & 0.69 & 1.00 & & & & & & & & & \\
\hline 23 & -0.08 & -0.29 & 0.31 & 0.43 & 0.52 & 0.40 & 0.36 & 0.43 & 0.19 & 0.23 & 0.42 & 0.41 & 0.88 & 0.45 & 0.18 & -0.35 & 0.25 & -0.10 & 0.48 & 0.41 & 0.16 & -0.27 & 1.00 & & & & & & & & \\
\hline 24 & 0.21 & -0.20 & -0.07 & 0.31 & 0.09 & 0.28 & 0.20 & 0.25 & 0.19 & 0.39 & 0.43 & 0.43 & 0.39 & 0.54 & 0.36 & -0.14 & -0.03 & 0.38 & 0.24 & 0.17 & 0.17 & 0.03 & 0.43 & 1.00 & & & & & & & \\
\hline 25 & 0.49 & -0.01 & -0.12 & -0.03 & -0.21 & -0.14 & -0.27 & 0.48 & -0.11 & 0.78 & -0.12 & -0.09 & 0.16 & 0.30 & 0.82 & 0.32 & 0.35 & 0.83 & -0.22 & -0.19 & -0.04 & 0.18 & 0.11 & 0.54 & 1.00 & & & & & & \\
\hline 26 & 0.07 & 0.04 & -0.04 & -0.33 & -0.15 & -0.12 & -0.32 & 0.09 & -0.15 & 0.13 & -0.49 & -0.49 & -0.33 & -0.18 & 0.23 & 0.68 & 0.25 & 0.52 & -0.48 & -0.47 & -0.13 & 0.39 & -0.29 & -0.04 & 0.38 & 1.00 & & & & & \\
\hline 27 & 0.16 & 0.16 & -0.17 & 0.34 & 0.16 & 0.06 & 0.14 & -0.29 & 0.46 & -0.24 & 0.62 & 0.59 & 0.32 & 0.06 & -0.31 & -0.27 & -0.53 & -0.20 & 0.54 & 0.47 & 0.24 & -0.15 & 0.31 & 0.35 & -0.13 & -0.29 & 1.00 & & & & \\
\hline 28 & 0.27 & -0.19 & -0.19 & 0.44 & 0.10 & 0.02 & 0.18 & 0.23 & 0.38 & 0.41 & 0.41 & 0.41 & 0.47 & 0.28 & 0.43 & -0.22 & -0.08 & 0.47 & 0.19 & 0.21 & 0.12 & 0.00 & 0.27 & 0.57 & 0.64 & -0.07 & 0.08 & 1.00 & & & \\
\hline 29 & 0.09 & -0.30 & 0.14 & -0.16 & -0.13 & 0.14 & 0.03 & 0.62 & -0.25 & 0.79 & -0.32 & -0.32 & 0.11 & 0.45 & 0.82 & 0.26 & 0.62 & 0.58 & -0.35 & -0.33 & -0.18 & 0.03 & 0.15 & 0.49 & 0.72 & 0.22 & -0.30 & 0.38 & 1.00 & & \\
\hline 30 & 0.44 & -0.06 & -0.11 & 0.04 & -0.19 & -0.10 & 0.01 & 0.42 & 0.06 & 0.72 & -0.03 & -0.01 & 0.21 & 0.31 & 0.71 & 0.13 & 0.27 & 0.70 & -0.04 & -0.05 & 0.16 & 0.25 & 0.17 & 0.56 & 0.87 & 0.19 & -0.08 & 0.67 & 0.76 & 1.00 & \\
\hline 31 & 0.23 & -0.18 & -0.21 & -0.08 & -0.30 & -0.18 & 0.20 & 0.38 & 0.07 & 0.64 & -0.20 & -0.19 & -0.02 & 0.23 & 0.64 & 0.29 & 0.28 & 0.49 & -0.22 & -0.18 & 0.07 & 0.22 & -0.15 & 0.33 & 0.66 & 0.24 & -0.19 & 0.47 & 0.66 & 0.74 & 1.00 \\
\hline
\end{tabular}


Table 2. Principal component analysis of the correlation between the 31 variables of Proteocephalus spp. complex.

\begin{tabular}{|c|c|c|c|c|}
\hline \multicolumn{5}{|c|}{$\begin{array}{l}\text { Eigenvalues and proportion of the variance expressed by the first four principal } \\
\text { components }\end{array}$} \\
\hline Eigenvalue & 14.013 & 9.011 & 4.725 & 3.539 \\
\hline Percent & 33.466 & 21.455 & 11.255 & 8.427 \\
\hline Cumulative & 33.366 & 54.822 & 66.073 & 74.501 \\
\hline \multicolumn{5}{|c|}{ Coefficient of each variable on the first three principal component } \\
\hline Variable & PCA1 & PCA2 & PCA3 & \\
\hline 1 & 0.061 & 0.273 & 0.598 & \\
\hline 2 & 0.330 & -0.308 & 0.582 & \\
\hline 3 & -0.286 & 0.120 & -0.678 & \\
\hline 4 & 0.361 & 0.564 & -0.232 & \\
\hline 5 & 0.119 & 0.451 & -0.715 & \\
\hline 6 & -0.089 & 0.421 & -0.695 & \\
\hline 7 & 0.133 & 0.457 & -0.621 & \\
\hline 8 & -0.596 & 0.509 & -0.184 & \\
\hline 9 & 0.640 & 0.297 & 0.305 & \\
\hline 10 & -0.740 & 0.569 & 0.110 & \\
\hline 11 & 0.818 & 0.525 & 0.188 & \\
\hline 12 & 0.794 & 0.535 & 0.178 & \\
\hline 13 & 0.270 & 0.793 & -0.132 & \\
\hline 14 & -0.275 & 0.679 & -0.284 & \\
\hline 15 & -0.776 & 0.556 & 0.115 & \\
\hline 16 & -0.541 & -0.391 & 0.170 & \\
\hline 17 & -0.817 & 0.074 & -0.323 & \\
\hline 18 & -0.607 & 0.265 & 0.566 & \\
\hline 19 & 0.832 & 0.377 & 0.159 & \\
\hline 20 & 0.790 & 0.338 & 0.207 & \\
\hline 21 & 0.594 & 0.159 & 0.580 & \\
\hline 22 & 0.029 & -0.176 & 0.705 & \\
\hline 23 & 0.174 & 0.717 & -0.309 & \\
\hline 24 & -0.051 & 0.737 & 0.212 & \\
\hline 25 & -0.603 & 0.503 & 0.554 & \\
\hline 26 & -0.508 & -0.270 & 0.295 & \\
\hline 27 & 0.575 & 0.287 & 0.040 & \\
\hline 28 & -0.059 & 0.720 & 0.334 & \\
\hline 29 & -0.732 & 0.456 & 0.191 & \\
\hline 30 & -0.471 & 0.588 & 0.534 & \\
\hline 31 & -0.526 & 0.325 & 0.493 & \\
\hline
\end{tabular}

The differences between the material studied herein and the OD were: scolex width, 250-520 (OD = 151-154); presence of unicellular glands in the apex (observed by de Chambrier and Vaucher, 1999 in PM), external margin of suckers and in the proliferation zone (not mentioned in the OD); usually visible microtriches (OD $=$ without "spines"); morphological variation was observed in the shape of proglottides, with immature segments being always wider than long, but mature and gravid proglottides wider than long, quadrangular or longer than wide (OD did not mention the high variability present in the shape of proglottides); ovary medullary with slight dorsal outgrowth reaching cortex in cross sections, also observed by de Chambrier and Vaucher (1999) (OD = no figures of cross sections and no comments on this feature in the text); ovarian lobes flattened to bilobed, sometimes the lobes expanded anteriorly in gravid proglottides, as in P. bagri; vitelline follicles medullary and paramuscular to dorsal and ventral cortex in cross sections (OD $=$ no figures of cross sections), interrupted by vagina and cirrus pouch, reaching $96-98 \%$ of total proglottis length with a slight tendency to posterior concentration of follicles; vagina always posterior to cirrus pouch $(\mathrm{OD}=$ anterior according to the text, posterior as shown in Plate $2 \mathrm{c}, \mathrm{d}$, f), with sphincter, observed by de Chambrier and Vaucher, 1999 (OD = without sphincter); absence of genital atrium $(\mathrm{OD}=$ presence of genital atrium, not shown in Plate 2c, d); total number of testes 91-239 $(\mathrm{OD}=109-137)$; total number of uterine branches 40 $100(\mathrm{OD}=34-52)$.

\section{Principal Component Analysis}

Measurements of 31 variables of 42 specimens of Proteocephalus spp. from $R$. quelen in 3 localities were used to construct a correlation matrix (Table 1). Correlations between 31 variables illustrate that the size 
of some structures may vary in the same direction (e.g., 11 with 19 and $20 ; 12$ with 19 and 20 or 10 with 25,29 and 30 ) or completely independently (e.g., 1 and 23 or 4 and 31 or 27 and 30) or inversely (e.g., 17 with 11 and 12). Highly correlated variables were eliminated from the analysis.

The first two principal components account for 55\% (Table 2) of the total variance. PC1, which represents $33 \%$, is characterised by positive and negative coefficients and variables. The multidimensional aspect of the correlations between 42 specimens is illustrated by their relative position on the first two components (Fig. 18A) and the first component with the third component (Fig. 18B). The analysis suggests that the nominal taxa represent a complex of two discrete but cryptic species. There was no overlapping between specimens of $P$. bagri and $P$. rhamdiae (Fig. 18A, PC1 vs. PC2), but both groups were rather close to one another. Figure 18B (PC1 vs. PC3) shows that $P$. rhamdiae overlapped the area occupied by $P$. bagri, and only few specimens of $P$. bagri invaded the area of $P$. rhamdiae. Thus, in the second plane of the PCA, separation between both species is not clearly established.

The characters that most contributed to the differentiation of the two species were: $10,11,12,15,17,18$, 19,20 and 29 in component 1; 13, 23, 24 and 28 in component 2 (Table 2), and 5 and 22 in component 3.

\section{DISCUSSION}

Due to the confusion concerning the validity of Rhamdia sapo (Valenciennes, 1840), type host of $P$. bagri and $P$. rhamdiae, the results of the monograph of Silvergrip (1996) were considered. This author made a revision of the species of Rhamdia and synonymized $R$. sapo (Valenciennes, 1840) and $R$. guatemalensis (Günther, 1864), among others, with R. quelen (Quoy et Gaimard, 1824). Geographical distribution of the genus Rhamdia Bleeker, 1858 is restricted to the Neotropical region. The northernmost natural limit is central Mexico and the southernmost is Buenos Aires, Argentina.

Holcman-Spector and Mañé-Garzón (1988) justified the creation of $P$. bagri and $P$. rhamdiae (table $3, \mathrm{p}$. 154) on the basis of the shape of proglottides, number of testes, position of vagina to cirrus pouch, ratio of uterus width to proglottis width, ratio of cirrus pouch length to proglottis width, and number of uterine branches. These characters were apparently useful because the authors studied specimens having the extremes of variation of such characters in P. bagri and P. rhamdiae. Moreover, they failed to note several morphological features and they studied a small number of specimens ( 7 of $P$. bagri and 7 of $P$. rhamdiae). When a large number of specimens of $P$. bagri and $P$. rhamdiae was studied in the present work, the shape of proglottides used by Holcman-Spector and Mañé-Garzón appeared to be doubtful due to the morphological variation in $P$. rhamdiae; also some other features and measurements (e.g., scolex width, number of testes) overlapped. Two different morphological forms of the strobila were found within populations of $P$. rhamdiae in $R$. quelen, a phenotype with wide and elongated gravid proglottides and another one with only wide gravid proglottides. Considerable variation in the shape of proglottides was found in Proteocephalus exiguus La Rue, 1911 from different fish hosts (Hanzelová et al. 1995a, b) and in $P$. neglectus La Rue, 1911 from the same fish host (Hanzelová and Špakulová 1992). Due to the variability of proglottis shape, some specimens of $P$. rhamdiae are grouped with $P$. bagri (Figs. 18A, B). There is a high probability of misidentification of $P$. bagri with $P$. rhamdiae because morphometric characters vary slightly.

Based on the results of our morphological study and PCA, the most useful features to distinguish these species are: (1) the shape of gravid proglottides, which is constant in of $P$. bagri (always elongate) but considerably variable in $P$. rhamdiae $(20 \%$ of specimens having strobila with wide and elongate proglottides); this feature was observed in hosts of the same size and from the same locality; (2) mean number of the testes, the range being wider than previously described for both species, and mostly overlapping; however, the mean value is useful to discriminate them; (3) vitelline follicles; a detailed description of their topography helps in the discrimination since P. bagri has vitelline follicles concentrated in the mid-lateral region of proglottides, whereas in $P$. rhamdiae follicles are dispersed in the mid-lateral region; (4) degree of development of the internal longitudinal musculature; (5) mean value of uterine branches; (6) ratio of cirrus pouch length to proglottis width. Based on PCA results there are some useful meristic characters: shape of mature and gravid proglottides (characters 10, 11, 18 and 19); ovary width in mature and gravid proglottides (characters 12 and 20); ovary length in mature proglottides (character 20), and genital pore position in mature proglottis (character 15).

In view of the present findings it can be concluded that $P$. bagri and $P$. rhamdiae are valid species and that the latter exhibits considerable intraspecific variation. However, validity of these species needs to be confirmed by molecular and genetic studies in order to support these results. Since the type material of $P$. bagri and $P$. rhamdiae has been lost, neotypes were designated for both species on the basis of Uruguayan material from the type host and type locality.

Acknowledgements. I would like to express my gratitude to the authorities of the following museums that allowed me to study specimens: Colección Helmintológica, Laboratorio de Zoología de Invertebrados, Facultad de Humanidades y Ciencias, Uruguay (Dr. R. Ponce de León); Muséum d'Histoire naturelle, Geneva, Switzerland (Dr. A. de Chambrier) and Colección Nacional de Helmintos, Instituto de 
Biología, Universidad Nacional Autónoma de México, México (Dr. L. García-Prieto). I am indebted to Dr. V. Ivanov and Lic. A. Ribichich for valuable advice, assistance and consultation about principal component analysis and for helpful discussions during the preparation of the manuscript and its critical revision, to Dr. J.E. Wright (Argentina) for his help in improving the English of the manuscript, and to the reviewers for constructive criticism. This study was supported by grants from the Agencia Nacional de Promoción Científica y Tecnológica (proyecto BID 1201 OC-AR PICT 1-6604) and Consejo Nacional de Investigaciones Científicas y Técnicas (proyecto PIP 4545/96).

\section{REFERENCES}

BRAY R., des CLERS S.A. 1992: Multivariate analysis of metrical features in the Lepidapedon elongatum (Lebour, 1908) species-complex (Digenea, Lepocreadidae) in deep and shallow water gadiform fishes of the NE Atlantic. Syst. Parasitol. 21: 223-232.

CREMONTE F., NAVONE G., ETCHEGOIN J. 2000: Morphological studies of Ancyracanthopsis winegardi Wong \& Anderson, 1990 (Nematoda: Acuarioidea) and larval stages of acuariid nematodes parasitic in Larus dominicanus Lichtenstein (Aves: Laridae) from Argentina. Syst. Parasitol. 45: 135-140.

de CHAMBRIER A., VAUCHER C. 1999: Proteocephalidae et Monticelliidae (Eucestoda: Proteocephalidea) parasites de poissons d'eau douce au Paraguay, avec descriptions d'un genre nouveau et de dix espèces nouvelles. Rev. Suisse Zool. 106: 165-240.

FLORES C., BACCALÁ N. 1998: Multivariate analysis in the taxonomy of two species of Tylodelphys Diesing, 1850 (Trematoda: Diplostomidae) from Galaxias maculatus (Teleostei: Galaxiidae). Syst. Parasitol. 40: 221-227.

HANZELOVÁ V., SCHOLZ T., FAGERHOLM H.-P. 1995a: The synonymy of Proteocephalus neglectus La Rue, 1911 with $P$. exiguus La Rue, 1911, two fish cestodes from the Holartic Region. Syst. Parasitol. 30: 173-185.

HANZELOVÁ V., ŠNÁBEL V., ŠPAKULOVÁ M., KRÁLOVÁ I., FAGERHOLM H.-P. 1995b: A comparative study of the fish parasites Proteocephalus exiguus and $P$. percae (Cestoda: Proteocephalidae): morphology, isoenzymes, and karyotypes. Can. J. Zool. 73: 1191-1198.

HANZELOVÁ V., ŠNÁBEL V., KRÁL'OVÁ I., SCHOLZ T., D'AMELIO S. 1999: Genetic and morphological variability in cestodes of the genus Proteocephalus: geographical variation in Proteocephalus percae populations. Can. J. Zool. 77: 1450-1458.

HANZELOVÁ V., ŠPAKULOVÁ M. 1992: Biometric variability of Proteocephalus neglectus (Cestoda: Proteocephalidae) in two different age groups of the rainbow trout from the Dobšiná water reservoir (East Slovakia). Folia Parasitol. 39: 307-316.
HÖGLUND J., THULIN J. 1992: Identification of Diplostomum spp. in the retina of perch Perca fluviatilis and the lens of roach Rutilus rutilus from the Baltic Sea - an experimental study. Syst. Parasitol. 21: 1-19.

HOLCMAN-SPECTOR B., MAÑÉ-GARZÓN F. 1988: Two new species of the genus Proteocephalus Weinland, 1858 (Proteocephalidea, Eucestoda) of freshwater fishes Rhamdia sapo (Valenciennes, 1840) from Uruguay. Parasitología al Día 12: 148-154.

JACKSON J.A., TINSLEY R.C. 1998: Paramphistome digeneans from Xenopus species (Pipidae) in Africa: taxonomy, host-specificity and biogeography. Syst. Parasitol. 40: $143-160$.

LANGERON M. 1949: Précis de Microscopie, 7th ed. Masson \& Cie, Paris, 1429 pp.

REGO A.A., CHUBB J.C., PAVANELLI G.C. 1999: Cestodes in South American freshwater teleost fishes: keys to genera and brief description of species. Rev. Bras. Zool. 16: 299-367.

SCHOLZ T., HANZELOVÁ V. 1994: Taxonomic study of two Proteocephalus species (Cestoda: Proteocephalidae) parasitising coregonid fishes: the synonymy of $P$. fallax La Rue, 1911 with $P$. exiguus La Rue, 1911. Syst. Parasitol. 27: 1-12.

SCHOLZ T., HANZELOVÁ V., KRÁL'OVÁ I., GRIFFITHS D. 1998: Synonymy of Proteocephalus pollanicola Gresson, 1952 (Cestoda: Proteocephalidae), a parasite of pollan, Coregonus autumnalis pollan, with $P$. exiguus La Rue, 1911. Syst. Parasitol. 40: 35-41.

SILVERGRIP A.M.C. 1996: A systematic revision of the Neotropical catfish genus Rhamdia (Teleostei, Pimelodidae). Swedish Museum of Natural History, Stockholm, 156 pp. +8 pls.

TINSLEY R.C., JACKSON J.A. 1998: Speciation of Protopolystoma Bychowsky, 1957 (Monogenea: Polystomatidae) in hosts of the genus Xenopus (Anura: Pipidae). Syst. Parasitol. 40: 93-141. 